The reasons for the low rate of lesion detection are not difficult to find. Firstly, most patients suffering from ill-defined cranial symptoms such as headache, giddiness, vertigo, alterations of consciousness or concentration, or more clearly recognizable disturbances such as epilepsy or syncope have no identifiable cause discovered in the absence of persisting physical signs. Secondly, even in those patients where a mass lesion is discovered (Bull and Zilkha, 1968) the skull $x$-ray film may remain within normal limits. This is not altogether surprising as most intracranial mass lesions will produce pronounced disturbance of function before the classical radiological signs of raised intracranial pressure or displacement of calcified midline structures are recognized. Finally, the pathological incidence of benign tumours or granulomata, for example, tuberculomata, which have undergone partial calcification and would thus be readily observed on the $x$-ray films-is so low that such a lesion is most unlikely to be found as the cause of cranial symptoms.

Though it is not possible in the present series to measure the clinical contribution to the low agreement percentages, undoubtedly it is an important factor and, unlike those inherent in radiological methods of investigation, little attention has been given to its improvement. At present the teaching of radiology to undergraduates and medical and surgical postgraduates at most centres appears largely intended to give the student a small degree of diagnostic ability. The progressive refinement of radiological methods and interpretation makes the value of this type of training increasingly doubtful. Though interesting from an educational standpoint it contributes little to the understanding of the practical application, value, and limitations of radiological investigations. If diagnostic radiology is to be used effectively then its application rather than interpretation in the clinical situation must become he main focus of attention in clinical training programmes.

\section{REFERENCES}

Bull, J. W. D., and Zilkha, K. J. (1968). British Medical fournal, 4, 569 Cook, P. L. (1966). British Medical fournal, 2, 351

Cooley, R. N. (1961). American fournal of the Medical Sciences, 242, 628 Edelstyn, G. A., Gillespie. P. J., and Grebbell, F. S. (1967). Clinical Radiology, 18, 158

Rawson, M. D. (1965). Lancet, 1, 698.

Reid, L., and Millard, F. J. C. (1964). Clinical Radiology, 15, 307.

Standertskjöld-Nordenstam, C.-G. (1965). Acta Radiologica, Suppl. No. 239.

Sutherland, G. R., Leask, E., and Samuel, E. (1968). Clinical Radiology, 19,269 .

\title{
Treatment of Menorrhagia with Tranexamic Acid. A Double-blind Trial
}

\author{
SHEI LA T. CALLENDER, ${ }^{*}$ M.D., F.R.C.P. ; G. T. WARNER, † D.PHIL. ; E. COPE, $\ddagger$ M.D., F.R.C.o.G.
}

\begin{abstract}
Summary: In a double-blind trial tranexamic acid (Cyclokapron) $1 \mathrm{~g}$. four times a day for the first four days of menstruation, significantly decreased menstrual blood loss in women with menorrhagia for which no organic cause had been found. No difference in side-effects was noted between the active and placebo treatment.
\end{abstract}

\section{Introduction}

Apart from its social inconvenience menorrhagia can cause anaemia, which may be difficult to combat even with continuous iron therapy. Hormone therapy may improve the symptom, but the recent adverse publicity given to the "pill" makes such treatment unacceptable for some. An increase in plasminogen activators in the endometrium has been found on the first day of the menstrual period in women with menorrhagia compared with those with normal menstrual loss (Rybo, 1966); the use of an antifibrinolytic agent to reduce the loss therefore seems logical. The present paper reports the results of a double-blind trial with a new antifibrinolytic agent tranexamic acid (Cyclokapron; trans-4-aminomethylcyclohexanecarboxylic acid) in the treatment of 16 women suffering from excessive menstrual loss.

\section{Patients and Methods}

The patients had either presented to the medical clinic with iron-deficiency anaemia which, from the history and other negative investigations, appeared to be due to heavy menstrual loss or they had been referred direct to the gynaecologist with a complaint of menorrhagia. Before 2dmission to the trial each had a gynaecological examination and

- First Assistant, Nuffield Department of Clinical Medicine.

+ Research Officer, Nuffield Department of Clinical Medicine.

$\$$ Consultant Obstetrician and Gynaecologist.

Radcliffe Infirmary, Oxford. dilatation and curettage was performed. If no significant clinical or histological abnormality was found the possibility of treatment with tranexamic acid was discussed with the patient and the purpose of the trial was explained fully.

Originally 20 patients agreed to take part in the investigation, but four did not complete the trial and are not included in the analysis-two elected to have a hysterectomy rather than continue with the trial, one was found to be losing blood from an undefined source between the menstruations, and one failed to return for follow-up.

Menstrual loss was measured with the Oxford total body counter (Warner and Oliver, 1966). In each case the study was started shortly after a menstrual period. About $2-4 \mu \mathrm{Ci}$ ${ }^{59} \mathrm{Fe}$ ferric citrate was given intravenously, and two weeks later the total body count was measured for the baseline value. Thereafter each patient reported for a total body count at two-weekly intervals, the activity on each occasion being related to the previous count. The blood loss between each visit was estimated by multiplying percentage loss of radioactivity by the estimated blood volume (Holt et al., 1967). The blood volume was obtained from the weight and height of the subject (Nadler et al., 1962).

For the first three menstrual periods (control blood loss) no treatment was given; over the second three menstrual periods each patient was given, at the visit before each menstruation was due, a bottle containing 32 tablets labelled $\mathrm{A}$, and she was instructed to take two tablets four times a day for the first four days of the menstruation. She was also given a supply of sanitary pads (Dr. White's), and asked to keep a note of how many pads she used each day. For the third three months she was similarly instructed but tablets $\mathrm{A}$ were replaced by tablets B.

The tablets were either tranexamic acid $0.5 \mathrm{~g}$. per tablet or a placebo of similar size and appearance. The order of treatments was randomized, and neither the patients nor those conducting the study knew the identity of tablets A and B. A slip was attached to each bottle on which the patient recorded 
Table I.-Details of Patients Taking Part in the Investigation on the Effect of Tranexamic Acid in Menorrhagia

\begin{tabular}{|c|c|c|c|c|c|c|c|c|}
\hline \multirow{2}{*}{$\begin{array}{l}\text { Patient } \\
\text { No. }\end{array}$} & \multirow[t]{2}{*}{ Age } & \multirow[t]{2}{*}{ Parity } & \multirow[t]{2}{*}{ Duration of Menorrhagia } & \multicolumn{2}{|c|}{$\mathrm{Hb}(\mathrm{g} . / 100 \mathrm{ml})}$. & \multicolumn{2}{|c|}{$\begin{array}{c}\text { Serum Iron } \\
(\mu \mathrm{g} . / 100 \mathrm{ml} .)\end{array}$} & \multirow[t]{2}{*}{ Remarks } \\
\hline & & & & 1 & 2 & 1 & 2 & \\
\hline $\begin{array}{l}1 \\
2\end{array}$ & $\begin{array}{l}34 \\
42\end{array}$ & $\begin{array}{l}3 \\
6\end{array}$ & $\begin{array}{l}\text { Indefinite, probably years } \\
15 \text { years }\end{array}$ & $\begin{array}{l}10 \cdot 7 \\
14.4\end{array}$ & $\begin{array}{r}8 \cdot 0 \\
14 \cdot 8\end{array}$ & $\begin{array}{l}70 \\
52\end{array}$ & $\begin{array}{l}25 \\
70\end{array}$ & $\begin{array}{l}\text { Chronically anaemic. Previous treatment with iron } \\
\text { Blood transfusion with } 3 \text { last pregnancies. Never iron } \\
\text { therapy }\end{array}$ \\
\hline $\begin{array}{l}5 \\
7\end{array}$ & $\begin{array}{l}45 \\
36\end{array}$ & $\begin{array}{l}0 \\
3\end{array}$ & $\begin{array}{l}\text { Indefinite } \\
\text { Indefinite }\end{array}$ & $\begin{array}{l}12.9 \\
12.4\end{array}$ & $\begin{array}{l}11 \cdot 7 \\
10 \cdot 7\end{array}$ & $\begin{array}{r}280 \\
47\end{array}$ & $\underline{288}$ & $\begin{array}{l}\text { Chronically anaemic. On iron throughout trial } \\
\text { Chronically anaemic. } \\
\text { before trial }\end{array}$ \\
\hline $\begin{array}{r}8 \\
9 \\
10 \\
11 \\
12 \\
13 \\
14 \\
15 \\
16\end{array}$ & $\begin{array}{l}33 \\
36 \\
48 \\
42 \\
38 \\
37 \\
48 \\
48 \\
42\end{array}$ & $\begin{array}{c}0 \\
3 \\
3 \\
2 \\
2 \\
2 \\
2 \\
\text { Miscarriage } \\
3 \\
1\end{array}$ & $\begin{array}{l}6 \text { months } \\
5 \text { months } \\
3 \text { years } \\
2 \text { years } \\
1 \text { year } \\
\text { Many years } \\
\text { Indefinite } \\
7 \text { years } \\
\text { 2-3 years }\end{array}$ & $\begin{array}{r}14 \cdot 8 \\
13 \cdot 8 \\
13 \cdot 8 \\
14 \cdot 8 \\
13 \cdot 2 \\
13 \cdot 5 \\
9 \cdot 2 \\
12 \cdot 0 \\
14 \cdot 1\end{array}$ & $\begin{array}{l}14.2 \\
13.5 \\
13.8 \\
11.8 \\
13.0 \\
13.8 \\
13.5 \\
12.0 \\
13.7\end{array}$ & $\begin{array}{l}76 \\
97 \\
85 \\
73 \\
74 \\
45 \\
19 \\
68 \\
53\end{array}$ & $\begin{array}{r}140 \\
21 \\
68 \\
77 \\
80 \\
52 \\
61 \\
155 \\
80\end{array}$ & $\begin{array}{l}\text { Never anaemic } \\
\text { Never anaemic } \\
\text { Never anaemic } \\
\text { Anaemic. Treated with iron before trial } \\
\text { Never anaemic } \\
\text { Anaemic. Treated with iron before and during trial } \\
\text { Anaemic. Treated with iron throughout trial } \\
\text { Anaemic. Treated with iron before trial } \\
\text { Turned down as blood donor after about } 20 \text { donations. } \\
\text { Given iron }\end{array}$ \\
\hline $\begin{array}{l}17 \\
18 \\
20\end{array}$ & $\begin{array}{l}36 \\
39 \\
36\end{array}$ & $\begin{array}{l}2 \\
4 \\
+2 \\
2 \text { mis. }\end{array}$ & $\begin{array}{l}3 \text { years } \\
2 \text { years } \\
3 \text { years }\end{array}$ & $\begin{array}{l}16 \cdot 9 \\
13 \cdot 4 \\
14 \cdot 5\end{array}$ & $\begin{array}{l}16 \cdot 0 \\
15 \cdot 0 \\
16 \cdot 0\end{array}$ & $\begin{array}{r}\overline{95} \\
137\end{array}$ & $\begin{array}{r}176 \\
168 \\
-\end{array}$ & $\begin{array}{l}\text { Treated before and during trial with iron } \\
\text { Treated with iron before and during trial } \\
\text { Treated with iron before trial }\end{array}$ \\
\hline
\end{tabular}

the date when menstruation started, the number of tablets taken, and the number of pads used each day. At each attendance she was asked to record her impression of the treatment and whether she had noted any side-effects. At the beginning of each three months of observation an additional dose of about $2-4 \mu \mathrm{Ci}$ of activity was given. A blood count was done and the serum iron and total iron-binding capacity were measured at the beginning and end of the trial.

\section{Results}

A subjective complaint of heavy menstrual loss had been present in all patients for from five months to several years (Table I). Four only of the 16 gave no history of ever having been treated for anaemia, and in three of these the history was relatively short-that is, one year or less-and in two (Patients 8 and 12) the dietary history suggested an exceptionally high intake of meat, which might be an added factor in the prevention of anaemia.

The other 12 patients either presented with anaemia or gave a history of treatment with iron some time in the past. Three continued iron therapy throughout the trial, and two of these showed an increase of more than $1 \mathrm{~g}$. of haemoglobin during this time. In contrast four who stopped treatment with iron showed a drop of more than $1 \mathrm{~g}$. of haemoglobin per $100 \mathrm{ml}$. during the nine months. Two patients had attempted to control the menorrhagia with hormone therapy, but this treatment was stopped before the trial. One patient had been taking megestrol as a contraceptive for eight years, and she continued to do so throughout the observations.

The mean loss per menstruation for the no treatment and placebo and tranexamic acid treatment in each subject is shown in Table II; the means for the groups as a whole were 197,185 , and $122 \mathrm{ml}$. respectively. Patient 9 had presented to the gynaecologist with a history of menorrhagia, but her mean loss during the control and placebo periods was normal. In the other patients the measurement of blood loss during the three months of no treatment confirmed a loss of more than $80 \mathrm{ml}$. per menstruation, which has been defined by Hallberg et al. (1966) as excessive. There was no significant difference between the no treatment and placebo treatment, but comparison of the observations on the loss with no treatment and with tranexamic acid showed a significant decrease in loss produced by the therapy $(t=3.44, \mathrm{P}<0.02)$; for tranexamic acid compared with the placebo $t=2.37, \mathrm{P}<0.05$.

The duration of the menstrual periods, the number of pads used, and the number of pills taken for the tranexamic acid and placebo treatment are shown in Table III. There was no significant difference in the duration of the menstrual loss for the two treatments, but a significant reduction occurred in the number of pads used in the treatment with tranexamic acid $(t=3.37, \mathrm{P}<0.01)$. A possible 96 tablets should have been taken for the three menstrual periods, but only six of those taking tranexamic acid took all the pills and only seven of those taking the placebo. In the active treatment group the total dose of tranexamic acid per menstruation varied from 10 to $16 \mathrm{~g}$., with a mean of $14 \mathrm{~g}$. The patients admitted to not taking all the tablets for various reasons not related to intolerance.

A few patients reported minor complaints which might be attributed to the tablets. One said that both tablets $A$ and $B$ made her feel "sickly." Two patients complained of "headache" or "feeling unwell" on taking tranexamic acid. Two others taking the placebo complained of "light-headed feelings" and "haziness." Several reported a striking

TABLE II.-Mean Blood Loss per Menstrual Period Measured by Total Body

\begin{tabular}{|c|c|c|c|c|c|c|c|c|}
\hline \multirow[b]{2}{*}{$\begin{array}{l}\text { Patient } \\
\text { No. }\end{array}$} & \multicolumn{2}{|c|}{ No Treatment } & \multicolumn{3}{|c|}{ Placebo } & \multicolumn{3}{|c|}{ Tranexamic Acid } \\
\hline & $\begin{array}{l}\text { No. of } \\
\text { Periods }\end{array}$ & $\begin{array}{l}\text { Mean } \\
\text { loss per } \\
\text { Period } \\
\text { (ml.) }\end{array}$ & $\begin{array}{l}\text { No. of } \\
\text { Periods }\end{array}$ & Order & $\begin{array}{l}\text { Mean } \\
\text { loss per } \\
\text { Period } \\
\text { (ml.) }\end{array}$ & $\begin{array}{c}\text { No. of } \\
\text { Periods }\end{array}$ & Order & $\begin{array}{c}\text { Mean } \\
\text { loss per } \\
\text { Period } \\
\text { (ml.) }\end{array}$ \\
\hline $\begin{array}{r}1 \\
2 \\
5 \\
7 \\
8 \\
9 \\
10 \\
11 \\
12 \\
13 \\
14 \\
15 \\
16 \\
17 \\
18 \\
20\end{array}$ & $\begin{array}{l}3 \\
3 \\
3 \\
3 \\
3 \\
3 \\
3 \\
3 \\
3^{*} \\
3 \\
3 \\
2 \\
3 \\
3 \\
3 \\
3\end{array}$ & $\begin{array}{r}274 \\
133 \\
160 \\
274 \\
125 \\
54 \\
172 \\
371 \\
359 \\
161 \\
99 \\
242 \\
218 \\
125 \\
276 \\
116\end{array}$ & $\begin{array}{l}3 \\
3 \\
3 \\
2 \\
2 \\
3 \\
3 \\
3 \\
3 \\
3 \\
3 \\
2 \\
3 \\
3 \\
3 \\
3\end{array}$ & $\begin{array}{l}2 \\
2 \\
1 \\
1 \\
1 \\
2 \\
2 \\
2 \\
1 \\
2 \\
1 \\
2 \\
1 \\
2 \\
2 \\
2\end{array}$ & $\begin{array}{r}185 \\
172 \\
176 \\
375 \\
278 \\
50 \\
78 \\
179 \\
103 \\
297 \\
270 \\
182 \\
34 \\
144 \\
348 \\
86\end{array}$ & $\begin{array}{l}2 \\
3 \\
3 \\
3 \\
3 \\
3 \\
2 \\
3 \\
3 \\
3 \\
3 \\
3 \\
3 \\
3 \\
3 \\
3\end{array}$ & $\begin{array}{l}1 \\
1 \\
2 \\
2 \\
2 \\
1 \\
1 \\
1 \\
2 \\
1 \\
2 \\
1 \\
2 \\
1 \\
1 \\
1\end{array}$ & $\begin{array}{r}125 \\
63 \\
136 \\
161 \\
155 \\
104 \\
78 \\
94 \\
285 \\
153 \\
152 \\
147 \\
86 \\
87 \\
97 \\
36\end{array}$ \\
\hline Mean & & 197 & & & 185 & & & 122 \\
\hline
\end{tabular}

* Total loss divided by 3 .

TABLE III.-Duration of Menstrual Loss, Number of Pads Used, and Number of Pills Taken During Placebo and Tranexamic Acid Treatment

\begin{tabular}{|c|c|c|c|c|c|c|}
\hline \multirow{2}{*}{$\begin{array}{l}\text { Patient } \\
\text { No. }\end{array}$} & \multicolumn{3}{|c|}{$\begin{array}{l}\text { Placebo. } \\
\text { Total for } 3 \text { Periods }\end{array}$} & \multicolumn{3}{|c|}{$\begin{array}{l}\text { Tranexamic Acid. } \\
\text { Total for } 3 \text { Periods }\end{array}$} \\
\hline & Days & Pads & Pills & Days & Pads & Pills \\
\hline $\begin{array}{r}1 \\
2 \\
5 \\
7 \\
8 \\
9 \\
10 \\
11 \\
12 \\
13 \\
14 \\
15 \\
16 \\
17 \\
18 \\
20\end{array}$ & $\begin{array}{l}20 \\
16 \\
18 \\
14 \\
21 \\
13 \\
23 \\
14 \\
21 \\
19 \\
14 \\
14 \\
17 \\
18 \\
18 \\
17\end{array}$ & $\begin{array}{c}114 \\
74 \\
56 \\
56 \\
101^{*} \\
46 \\
(T 47 \\
86 \\
96) \\
90 \\
94 \\
45 * \\
53 \\
46 \\
(T \quad 16+48) \\
110 \\
64\end{array}$ & $\begin{array}{l}94 \\
84 \\
96 \\
92 \\
64 \\
96 \\
96 \\
96 \\
96 \\
92 \\
78 \\
66 \\
92 \\
96 \\
96 \\
82\end{array}$ & $\begin{array}{l}24 \\
13 \\
18 \\
16 \\
24 \\
13 \\
18 \\
15 \\
19 \\
19 \\
18 \\
13 \\
19 \\
25 \\
24 \\
14\end{array}$ & $\begin{array}{c}136^{*} \\
46 \\
42 \\
51 \\
70 \\
44 \\
4 \mathrm{~T} 74+11) \\
55 \\
76 \\
61 \\
39 \\
42 \\
50 \\
(\mathrm{~T} 24+34) \\
83 \\
35 \\
35\end{array}$ & $\begin{array}{l}94 \\
87 \\
96 \\
78 \\
72 \\
96 \\
88 \\
96 \\
96 \\
96 \\
61 \\
66 \\
78 \\
96 \\
88 \\
60\end{array}$ \\
\hline Mean & & $74 t$ & & & $59 t$ & \\
\hline
\end{tabular}

$T=$ Tampax. All the other pads were standard "Dr. White's" issued to the patients. *Records for 2 periods only, hence number of days and pads calculated by $\times \frac{3}{2}$ to

make comparison valid.
tExcluding those in parentheses. 


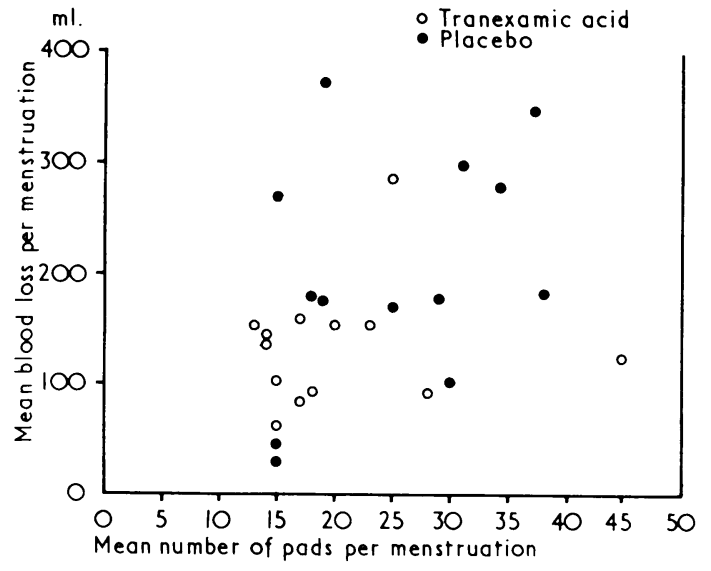

FIG. 1.-Mean number of pads used per menstruation plotted against the mean blood loss per menstruation.

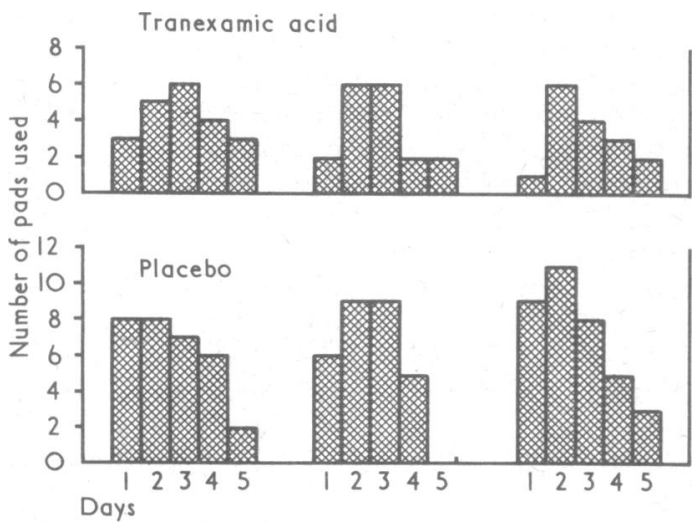

FIG. 2.-Number of sanitary pads used per day by patient 11 during the menstrual periods in the months of placebo and tranexamic acid treatment.

improvement in the menstrual flow, and made comments such as "marvellous tablets." Several were able to detect the more active treatment.

\section{Discussion}

The antifibrinolytic agent aminocaproic acid (epsilonaminocaproic acid, E.A.C.A.) has been used in the treatment of menorrhagia and found to be effective (Nilsson and Björkman, 1965; Nilsson and Rybo, 1965). The mean menstrual loss in 26 patients with menorrhagia studied by a double-blind trial was reduced with aminocaproic acid from 164.3 to $60.9 \mathrm{ml}$. To achieve this, however, the dose of aminocaproic acid was up to $25 \mathrm{~g}$./day, and at this level an appreciable number of side-effects were noted, such as nausea and faintness (Nilsson and Rybo, 1965).

Tranexamic acid is a more recently developed antifibrinolytic agent. Its use has already been reported in women with menorrhagia in Sweden and Belgium (Nilsson and Rybo, 1967; Vermylen et al., 1968). In these studies blood loss was measured by extracting the haemoglobin from the towels used by the women during menstruation. Vermylen et al. (1968) found a reduction in loss of $35 \%$. Nilsson and Rybo (1967) obtained a reduction of $38 \%$ with a total dose of $12 \mathrm{~g}$. per period, but by increasing the dose to $24 \mathrm{~g}$. $(6 \mathrm{~g}$. for four days) the mean reduction in loss was $51 \%$. The total body counter gives a relatively imprecise measurement of blood loss; nevertheless, we obtained a mean reduction of menstrual blood loss of about $36 \%$ with doses of tranexamic acid varying from 10 to $16 \mathrm{~g}$. per period.

Vermylen et al. (1968) did not find any reduction in the number of towels used during the active treatment, but in our observations this seemed to be the simplest and most sensitive way to detect reduction of blood loss. When more sophisticated methods are not available this would appear to be a good method for assessing the results of treatment, provided that a standard type of sanitary pad is used. There is little if any correlation between the number of pads used and the measured blood loss taking the patients as a whole (Fig. 1), but for any individual patient the amount lost is usually reflected by the number of pads she uses (Fig. 2).

In most cases tranexamic acid did not return the blood loss to normal; nevertheless, it is likely to prove a helpful agent where hormone therapy is not indicated and hysterectomy is not desired. The experience of Nilsson and Rybo (1967) suggests that larger doses would be more effective. With the dosage schedule used in this trial the side-effects were insignificant and did not differ from those produced by the placebos. One question, however, which will clearly need to be answered is whether tranexamic acid will show an advantage over hormone therapy from the point of view of thrombosis. On the basis of five years' clinical experience Nilsson et al. (1965) considered that the other antifibrinolytic agent aminocaproic acid could not be regarded as thrombogenic. It seems reasonable to hope that the same will apply to tranexamic acid.

We are grateful to Miss $M$. Alcock and Miss S. Parker for technical help and to Kabi Pharmaceuticals Limited for supplies of Cyclokapron and a contribution towards the expenses of the investigation.

\section{REFERENCES}

Hallberg, L., Hogdahl A. M., Nilsson, L., and Rybo, G. (1966). Acta Obstetricia et Gynecologica Scandinavica, 45, 320.

Holt, J. M., Mayet, F. G. H., Warner, G. T., and Callender, S. T. (1967). British Medical fournal, 4, 86

Nadler, S. B., Hidalgo, J. U., and Bloch, T. (1962). Surgery, 51, 224.

Nilsson, I. M., Andersson, L., and Bjorkman, S. E. (1965). Acta Medica Scandinavica, Suppl. No. 448.

Nilsson, I. M., and Björkman, S. E. (1965). Acta Medica Scandinavica, 177,445 .

Nilsson, L., and Rybo, G. (1965). Acta Obstetricia et Gynecologica Scandinavica, 44, 467.

Nilsson, L., and Rybo, G. (1967). Acta Obstetricia et Gynecologica Scandinavica, 46, 572 .

Rybo, G. (1966). Acta Obstetricia et Gynecologica Scandinavica, 45, Suppl. No. 7 , p. 97.

Vermylen, J., Verhaegen-Declercq, M. L., Verstraete, M., and Fierens, F. (1968). Thrombosis et Diathesis Haemorrhagica, 20, 583.

Warner, G. T., and Oliver, R. (1966). Physics in Medicine and Biology, 11, 83. 